\title{
Iron and liver diseases
}

\author{
Silvia Fargion MD, Michela Mattioli PhD, Anna Ludovica Fracanzani MD, Gemino Fiorelli MD
}

\begin{abstract}
S Fargion, M Mattioli, AL Fracanzani, G Fiorelli. Iron and liver diseases. Can J Gastroenterol 2000;14(Suppl D): 89D-92D. A mild to moderate iron excess is found in patients with liver diseases apparently unrelated to genetic hemochromatosis. Iron appears to affect the natural history of hepatitis $\mathrm{C}$ virus-related chronic liver diseases, alcoholic liver disease and nonalcoholic steatohepatitis by leading to a more severe fibrosis and thus aiding the evolution to cirrhosis. A higher frequency of mutations of the HFE gene, the gene responsible for hereditary hemochromatosis, is found in patients with liver diseases and increased liver iron than in normal patients. Patients with excess iron are potentially at a higher risk of developing hepatocellular carcinoma. Iron depletion therapy could interfere with fibrosis development and possibly reduce the risk of liver cancer occurrence.
\end{abstract}

Key Words: Genetic hemochromatosis; Hepatitis C virus; Iron; Liver disease

\section{Le fer et les maladies du foie}

RÉSUMÉ : On observe, chez les patients atteints d'une hépatopathie, une surcharge légère ou modérée en fer, sans liens apparents avec l'hémochromatose génétique. Le fer semble modifier l'évolution naturelle des maladies chroniques du foie, liées au virus de l'hépatite $\mathrm{C}$, des hépatopathies alcooliques et de la stéatohépatite non alcoolique en menant à une fibrose encore plus marquée du foie, d'où formation d'un terrain propice à la cirrhose. Les mutations du gène HFE, le gène responsable de l'hémochromatose héréditaire, se rencontrent plus souvent chez les patients souffrant de maladies du foie et chez ceux qui ont une surcharge ferrique. Les patients présentant un surplus de fer sont plus prédisposés que les autres à l'hépatome. Au contraire, la déplétion martiale pourrait gêner l'installation de la fibrose et réduire ainsi les risques de cancer du foie.
A well-defined relation between iron excess and liver damage occurs in hereditary hemochromatosis (HHC). However, recently an excess of iron has also been found in people with chronic liver diseases apparently unrelated to $\mathrm{HHC}$, and it has been suggested that iron may play a role in these conditions by affecting their natural history.

\section{HEPATITIS B VIRUS AND HEPATITIS C VIRUS CHRONIC LIVER DISEASE}

In the 1970s, Lustbader et al (1) reported that hemodialysis patients with elevated levels of serum ferritin had a higher likelihood of developing persistent hepatitis B virus (HBV) infection than those with lower levels of serum ferritin. Later, increased values of transferrin saturation, serum ferritin and liver iron concentration (LIC) were found in a high proportion of patients with hepatitis $\mathrm{C}$ virus (HCV)- and HBV-related chronic liver disease (2-5). These findings motivated the use of phlebotomy in the therapy of patients with chronic hepatitis, because it was thought that iron depletion could improve liver function and possibly the natural history of the patients. However, phlebotomies were followed by a reduction of alanine aminotransferase that, in some cases, reached normal values, but HCV RNA concentration did not appear to be markedly affected by iron depletion (6-9). Iron has been included among the factors that are able to influence the response to alpha-interferon (IFN) therapy. Only $5 \%$ to $15 \%$ of patients with increased iron parameters have a response to IFN therapy versus $50 \%$ of those with normal iron status. A significant difference in LIC values between responders and nonresponders to IFN therapy was found, although the LIC of the majority of the nonresponders was in the upper part of the normal range (10-13). Recently, a correlation between the grade of hepatic iron deposits and histological severity was found $(14,15)$, suggesting that liver iron deposition could facilitate the evolution to cirrhosis.

This mini-review was prepared from a presentation made at the World Congress of Gastroenterology, Vienna, Austria, September 6 to 11, 1998 Dipartimento di Medicina Interna, Università di Milano, Ospedale Maggiore IRCCS, Milano, Italy

Correspondence and reprints: Professor Silvia Fargion, Dipartimento di Medicina Interna, pad. Granelli, Ospedale Maggiore IRCCS, Via F.

Sforza 35, 20122 Milano, Italy. Telephone +39-2-55033757, fax+39-2-55180241, e-mail silvia.fargion@unimi.it

Received for publication June 4, 1999. Accepted June 8, 1999 


\begin{tabular}{|c|c|c|c|c|}
\hline $\begin{array}{l}\text { Country } \\
\text { (reference) }\end{array}$ & $\begin{array}{c}\text { Number } \\
\text { of } \\
\text { patients }\end{array}$ & $\mathrm{C} 282 \mathrm{Y}$ & H63D & $\begin{array}{c}\text { Patients } \\
\text { with HFE } \\
\text { mutations }\end{array}$ \\
\hline $\begin{array}{l}\text { Great Britain } \\
(26)\end{array}$ & 41 & $44 \%(11 \%)$ & $31 \%(29 \%)$ & $68 \%(37 \%)$ \\
\hline $\begin{array}{l}\text { The Netherlands } \\
\text { (27) }\end{array}$ & 15 & $67 \%(17 \%)$ & $33 \%$ (NA) & $87 \%(\mathrm{NA})$ \\
\hline Italy (29) & 68 & $3 \%(1.5 \%)$ & $51 \%(24 \%)$ & $53 \%(25 \%)$ \\
\hline Australia (28) & 27 & $44 \%(12 \%)$ & $44 \%$ (NA) & $70 \%(\mathrm{NA})$ \\
\hline
\end{tabular}

Numbers in brackets indicate the frequency of control individuals from the same population. NA Not applicable

After the identification of the two mutations of the gene associated with HHC (HFE) (16), several authors analyzed the relationship among HFE mutations, iron status and severity of HCV. An English group studied a large series of patients with HCV-related chronic liver disease and found a significantly higher histological stage in patients positive for the C282Y mutation, the major mutation associated with $\mathrm{HHC}$, than in patients with the wild-type genotype (17). A similar study involving 113 Italian patients with HCV chronic liver disease showed that $43 \%$ of patients with iron overload carried HFE mutations. The frequency of C282Y was only marginally increased, while the allelic frequency of H63D, the second mutation associated with HHC that appears to cause a more subtle abnormality of iron metabolism, was significantly increased in HCV patients with iron overload compared with normal controls. The scores of histological grade (activity) and stage (fibrosis) were significantly increased in patients carrying HFE gene mutations compared with patients carrying the wild-type gene (18). In another study performed in Italy, a relation between iron status and progression to fibrosis was observed, and an interplay between genetic and acquired factors was postulated (19). However, no increase in the prevalence of HFE mutations and no correlation between HFE mutations and histology was observed by Shirazi et al (20) in a large series of patients with HCV-related chronic liver disease.

\section{PORPHYRIA CUTANEA TARDA}

A liver disease in which the pathogenic role of iron is better defined is porphyria cutanea tarda (PCT), although often several different hepatotoxic factors can be identified, among which the most important are alcohol and HCV $(21,22)$. The majority of patients with PCT have liver siderosis and increased body iron stores $(23,24)$. It has been proposed that increased liver iron may trigger the clinical manifestations of the disease because iron depletion by phlebotomy may induce a remission of cutaneous lesions and an improvement of liver function tests (25). A significantly increased frequency of the C282Y HFE mutation in patients with PCT was reported for the first time by Roberts et al (26) in a British series: the mutation was found on $30 \%$ of alleles from patients with PCT versus $5.9 \%$ of controls. Similar data were obtained in different countries (Table 1) $(27,28)$; however, Sampietro et al (29) did not confirm an association of PCT with the mutation strongly associated with $\mathrm{HHC}$ in northern European countries, but found that the second mutation of HFE, H63D, had a significantly higher frequency, being present in half of the patients with PCT.

\section{ALCOHOL-RELATED LIVER DISEASE}

In alcohol-related liver disease, defining iron overload, which in some cases may resemble that found in HHC, is difficult. This is partly due to the fact that the usual iron tests overestimate the iron status of patients with alcohol abuse. An induction of ferritin synthesis occurs during alcohol abuse, while complete alcohol abstinence is followed by normalization of ferritin levels in a few days (30). In addition, a role for iron in facilitating alcohol-induced liver damage has been recently suggested by experimental data from animal models. Tsukamoto et al (31) showed that the histological grading of liver fibrosis of rats fed with ethanol and small amounts of iron was markedly higher than that of rats fed with only ethanol, suggesting a synergistic effect of alcohol and iron that may lead to cirrhosis. The prevalence of HFE mutations was recently studied in alcohol-related liver disease. While Grove et al (32) did not find any correlation between HFE mutations and liver iron content or liver fibrosis, a preliminary study performed in 60 Italian patients with alcohol-related liver disease (33) found that the allelic frequency of both C282Y and H63D mutations was higher in these patients than in normal Italian controls, and that the frequency of mutations was significantly increased in patients with more severe liver damage. These results do not indicate a direct relation between iron and alcohol-related liver disease but suggest a possible role for HFE mutations in the susceptibility to alcohol toxicity.

\section{NONALCOHOLIC STEATOHEPATITIS}

Another disease of emerging importance in which iron appears to have a role is nonalcoholic steatohepatitis (NASH). Originally described in middle age, overweight and often diabetic women, more recently it has been recognized in larger groups of patients, often of male sex. Pathognomonic for NASH is the presence of steatosis associated with cellular inflammation in the presence or absence of fibrosis in the liver biopsy (34-36). Unexpectedly, more than $50 \%$ of patients in the different series had hyperferritinemia, whereas increased transferrin saturation was found in a much lower proportion of patients. In addition, patients with increased body iron and carrying the main HFE mutation (C282Y) have more severe liver disease (37). A dysmetabolic iron overload syndrome, partly resembling NASH, has been recently described by Moirand et al (38). In these patients increased serum ferritin was associated with increased LIC but normal transferrin saturation was identified; these typical features are thought to characterize a new iron overload entity. Recently, an increased frequency of HFE gene mutations was observed in Italian patients with NASH and 
hyperferritinemia (39), suggesting that the mutations of the HFE gene may affect the natural history of patients with fat accumulation in the liver.

\section{LIVER CANCER}

Finally, iron has been suggested to facilitate liver cancer occurrence, although its role in cancer development is still a matter of debate. Numerous clinical investigations have suggested that patients with excess iron have a greater than normal risk of developing cancer, and several experimental studies in animals have confirmed a relation between iron and cancer (40). Indirect support of the role of iron in cancer comes from recent findings in French patients who underwent orthotopic liver transplantation for liver cancer. The concentration of iron in extralesion, nonneoplastic tissue was markedly higher than in control patients without liver cancer. Increased liver iron stores were present in both patients with hepatocellular carcinoma that developed on a cirrhotic or noncirrhotic liver (41). In a similar series of Italian patients undergoing orthotopic liver transplantation for liver cancer, the values of LIC compati-

\section{REFERENCES}

1. Lustbader ED, Hann HWL, Blumberg BS. Serum ferritin as a predictor of host response to hepatitis B virus infection. Science 1983;220:423-5.

2. Bonkowsky HL, Banner BF, Rothmanal L. Iron and chronic viral hepatitis. Hepatology 1998;25:759-68.

3. Di Bisceglie AM, Axiotis CA, Hofnagle JH, Bacon BR. Measurements of iron status in patients with chronic hepatitis. Gastroenterology 1992;102:2108-13.

4. Piperno A, D'Alba R, Fargion S, et al. Liver iron concentration in chronic viral hepatitis: a study of 98 patients. Eur J Gastroenterol Hepat 1995;7:1203-8.

5. Isomura T, Yano M, Hayashi H, Sakamoto N. Excess iron in the liver of patients with chronic hepatitis C. J Clin Electron Microscopy 1992;25:231-7.

6. Bacon RB, Rebholz AE, Fried M, Di Bisceglie AM. Beneficial effect of iron reduction therapy in patients with chronic hepatitis $C$ who failed to respond to interferon-alpha. Hepatology 1993;18:150A. (Abst)

7. Hayashi H, Takikawa T, Nishimura N, Yano M, Isomura T, Sakamoto N. Improvement of serum aminotransferase levels after phlebotomy in patients with chronic active hepatitis $\mathrm{C}$ and excess hepatic iron. Am J Gastroenterol 1994;89:986-8.

8. Hayashi H, Takikawa T, Nishimura N, Yano M. Serum aminotransferase levels as an indicator of the effectiveness of venesection for chronic hepatits C. J Hepatol 1995;22:268-71.

9. Herrera JL. Effect of phlebotomy in patients with chronic hepatitis C who failed to respond to a prior course of interferon alpha-2B. Hepatology 1996;24:404A. (Abst)

10. Van Theil DH, Friedlander L, Fagiuoli S, Wright HI, Irish W, Gavaler JS. Response to IFN alpha therapy is influenced by the iron content of the liver. J Hepatol 1994;20:410-5.

11. Olynyk JK, Reddy KR, Di Bisceglie AM, et al. Hepatic iron concentration as a predictor of response to interferon alfa therapy in chronic hepatitis C. Gastroenterology 1995;108:1104-9.

12. Piperno A, Sampietro M, D’Alba R, et al. Iron stores, response to alpha-IFN therapy and effects of iron depletion in chronic hepatitis C. Liver 1996;16:248-54.

13. Fargion S, Fracanzani AL, Sampietro M, et al. Liver iron influences the response to interferon alpha therapy in chronic hepatitis $\mathrm{C}$. Eur J Gatroenterol 1997;9:497-503.

14. Ikura Y, Morimoto H, Johmura H, Fukui M, Sakurai M. Relationship between hepatic iron deposits and response to interferon in chronic hepatitis C. Am J Gastroenterol 1996;91:1367-73.

15. Barton AL, Banner BF, Cable EE, Bonkovsky HL. Distribution of iron ble with a diagnosis of $\mathrm{HHC}$ were found in $8 \%$ of the patients - a 20-fold higher frequency than expected in the Italian population (42). The absence of severe cirrhosis rules out the possibility that the high LIC could be only secondary to liver cirrhosis, as recently reported $(43,44)$. In addition, in two patients, hepatocellular carcinoma occurred in the absence of a pre-existing cirrhosis. Very recently a high prevalence of the HFE gene mutations has been reported in patients with liver cancer, in those with both normal and cirrhotic livers $(45,46)$. These results suggest that the increased iron in the liver may act as a promoter of neoplastic transformation in the presence of carcinogenic factors.

\section{CONCLUSIONS}

Excess iron is present in many patients with chronic liver disease, and mutations of the gene associated with HHC are often found in these patients. Evidence suggests that iron may affect the natural history of different liver diseases independent of etiology. Iron depletion therapy may improve the prognosis of patients with chronic liver disease and possibly reduce the risk of liver cancer.

in the liver predicts the response of chronic hepatitis $\mathrm{C}$ infection to interferon therapy. Am J Clin Pathol 1995;103:419-24.

16. Feder JN, Gnirke A, Thomas W, et al. A novel MHC class I-like gene is mutated in patients with hereditary haemochromatosis. Nat Genet 1996;13:399-408

17. Smith BC, Grove J, Guzail MA, et al. Heterozygosity for hereditary hemochromatosis is associated with more fibrosis in chronic hepatitis C. Hepatology 1998;27:1695-9.

18. Sampietro M, Boldorini R, Casatta A, et al. Severity of chronic hepatitis $\mathrm{C}$, iron overload, and mutations in the hemochromatosis gene (HFE). Hepatology 1998;28:462A. (Abst)

19. Piperno A, Vergani A, Malosio I, et al. Hepatic iron overload in patients with chronic viral hepatitis: role of HFE gene mutations. Hepatology 1998;28:1105-9.

20. Shirazi LKS, Datz C, Maier-Doserberger T, et al. The relation of iron status and hemochromatosis gene mutations in patients with chronic hepatitis C. Gastroenterology 1999;116:127-34.

21. Haberman HF, Rosemberg L, Menon LA. Porphyria cutanea tarda: comparison of cases precipitated by alcohol and estrogens. Can Med Assoc J 1975;113:633-55.

22. Fargion S, Piperno A, Cappellini MD, et al. Hepatitis $C$ virus and porphyria cutanea tarda: evidence of a strong association. Hepatology 1992;16:1322-6.

23. Fargion S, Fracanzani AL, Romano R, et al. Genetic hemochromatosis in Italian patients with porphyria cutanea tarda: possible explanation for iron overload. J Hepatol 1996;24:564-9.

24. Sampietro M, Fiorelli G, Fargion S. Iron overload in porphyria cutanea tarda. Haematologica 1999;84:248-53.

25. Lundvall $\mathrm{O}$, Weinfeld A, Lundin P. Iron storage in porphyria cutanea tarda. Acta Med Scand 1970;188:37-53.

26. Roberts AG, Whatley SD, Morgan RR, Worwood M, Elder GH. Increased frequency of the haemochromatosis Cys282Tyr mutation in sporadic porphyria cutanea tarda. Lancet 1997;349:321-3.

27. Santos M, Clevers HC, Marks JJM. Mutations of the hereditary hemochromatosis candidate gene HLA-H in porphyria cutanea tarda. N Engl J Med 1997;336:1327-8.

28. Stuart KA, Busfield F, Jazwinska EC, et al. The C282Y mutation in the hemochromatosis gene (HFE) and hepatitis $\mathrm{C}$ virus infection are independent cofactors for porphyria cutanea tarda in Australian patients. J Hepatol 1998;28:404-9.

29. Sampietro M, Piperno A, Lupica L, et al. High prevalence of the His63Asp HFE mutation in Italian patients with porphyria cutanea tarda. Hepatology 1998;27:181-4. 
30. Bell H, Skinningsrud A, Raknerud N, Try K. Serum ferritin and transferrin saturation in patients with chronic alcoholic and non-alcoholic liver diseases. J Intern Med 1994;236:315-22.

31. Tsukamoto H, Horne W, Kamimura S, et al. Experimental liver cirrhosis induced by alcohol and iron. J Clin Invest 1995;96:620-30.

32. Grove J, Daly AK, Burt AD, et al. Heterozygotes for HFE mutations have no increased risk of advanced alcoholic liver disease. Gut 1998;43:262-6.

33. Fargion S, De Feo TM, Fracanzani AL, et al. Iron and HFE mutations in patients with alcoholic liver disease. Hepatology 1998;28:670A. (Abst)

34. Bacon BR, Farahvash MJ, Janney CG, Neuschwander-Tetri BA. Nonalcoholic steatohepatitis: an expanded clinical entity. Gastroenterology 1994;107:1103-9.

35. Sheth SG, Gordon FD, Chopra S. Nonalcoholic steatohepatitis. Ann Intern Med 1997;126:137-45.

36. James OFW, Day CP. Non-alcoholic steatohepatitis (NASH): a disease of emerging identity and importance. J Hepatol 1998;29:495-501.

37. George DK, Goldwurm S, Macdonald GA, et al. Increased hepatic iron concentration in nonalcoholic steatohepatitis is associated with increased fibrosis. Gastroenterology 1998;114:311-8.

38. Moirand R, Mortaji AM, Loreal O, Paillard F, Brissot P, Deugnier Y. A new syndrome of liver iron overload with normal transferrin saturation. Lancet 1997;349:95-7.
39. Fargion S, Mattioli M, Fracanzani AL, et al. Heterozygosity for genetic hemochromatosis in patients with non-alcoholic steatohepatitis and hyperferritinemia. BIOIRON 1999,

World Congress on Iron Metabolism, Sorrento, May 23-28, 1999. (Abst)

40. Weimberg ED. Iron in neoplastic disease. Cancer 1983;4:223-33.

41. Turlin B, Juguet F, Moirand R, et al. Increased liver iron stores in patients with hepatocellular carcinoma developed on a noncirrhotic liver. Hepatology 1995;22:446-50.

42. Fargion S, Mattioli M, Sampietro M, et al. Iron as risk factor for hepatocellular carcinoma. J Hepatol 1998;28:93. (Abst)

43. Ludwig J, Hashimoto E, Porayko MK, Moyer TP, Baldus W. Hemosiderosis in cirrhosis: a study of 447 native livers. Gastroenterology 1997;112:882-8.

44. Fargion S, Mattioli M, Sampietro M, et al. Siderosis in cirrhosis: is genetic hemochromatosis ruled out? Gastroenterology $1998 ; 114: 623-4$.

45. Blanc JF, De Ledinghen V, Bernard PH, et al. Increased incidence of HFE C282Y mutations in patients with iron overload and hepatocellular carcinoma developed in non-cirrhotic liver. J Hepatol 2000;32:805-11.

46. Pirisi M, Tomiutto P, Uzzau A, et al. Carriage of HFE mutations and outcome of surgical resection ofr hepatocellular carinoma in cirrhotic patients. Cancer 2000;89:297-302. 


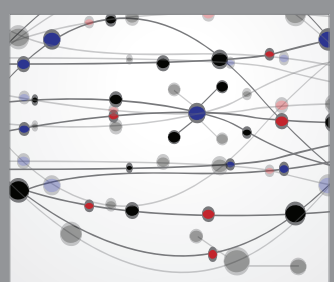

The Scientific World Journal
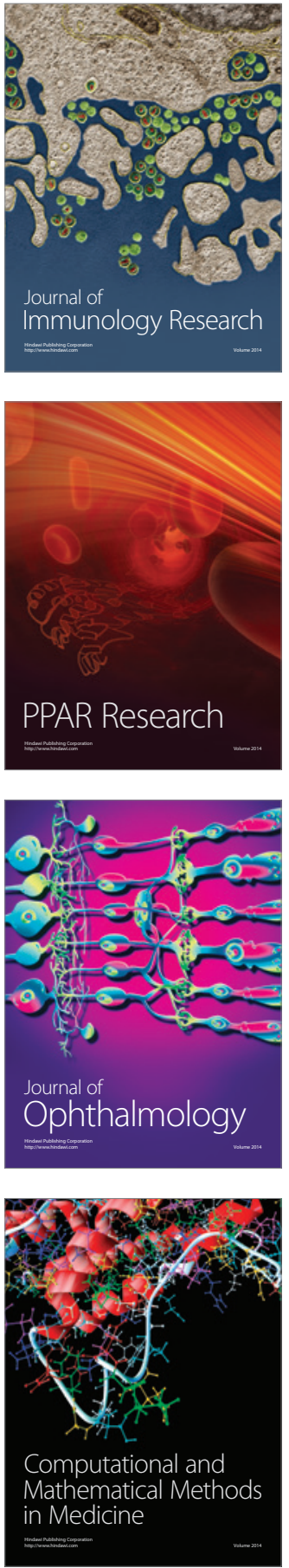

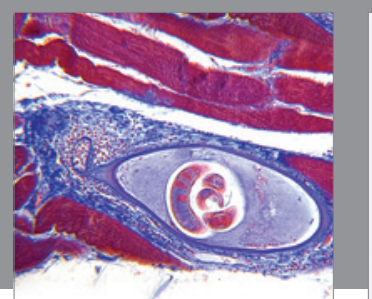

Gastroenterology Research and Practice

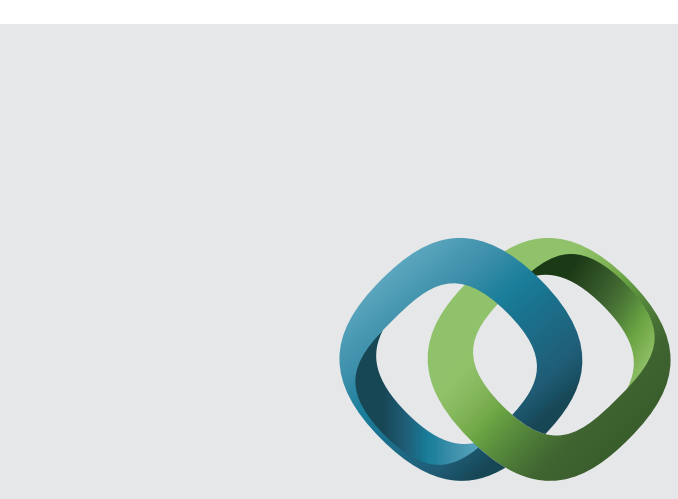

\section{Hindawi}

Submit your manuscripts at

http://www.hindawi.com
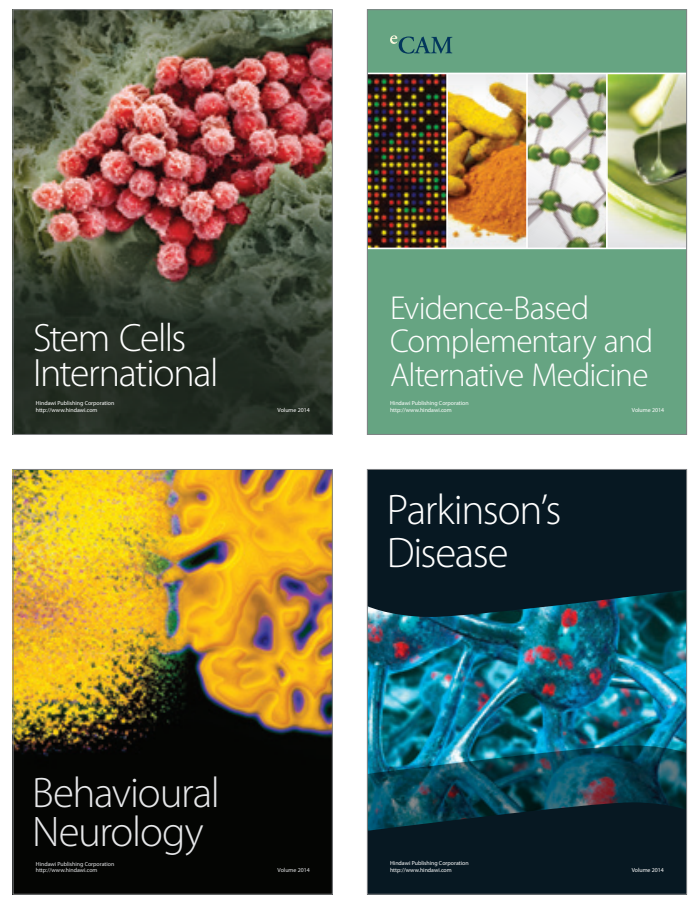
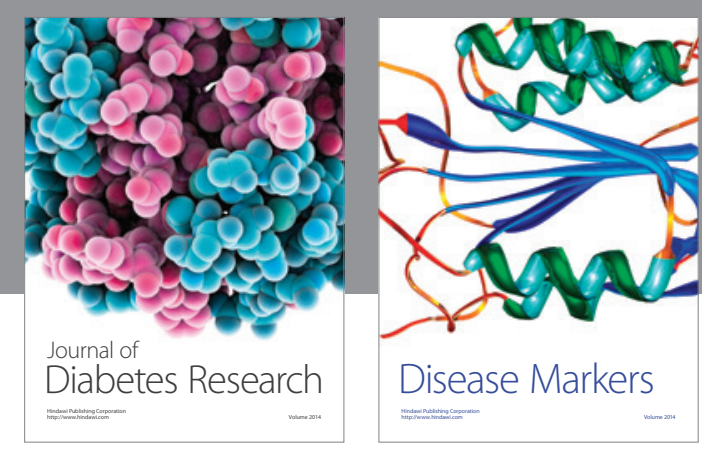

Disease Markers
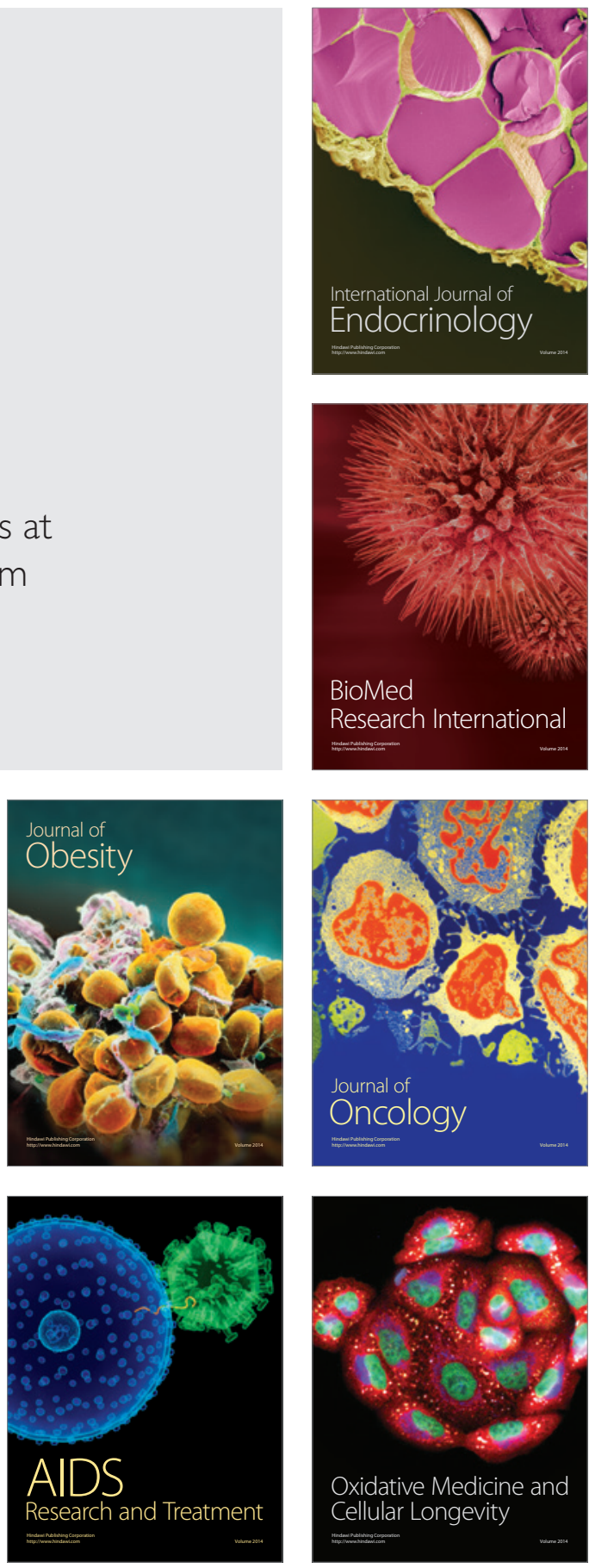